\title{
EKSISTENSI KEBUDAYAAN TOLONG MENOLONG (KASEISE) SEBAGAI BENTUK SOLIDARITAS SOSIAL PADA MASYARAKAT MUNA (Studi di Desa Mataindaha Kecamatan Pasikolaga)
}

\author{
Oleh: Adi Mandala Putra, Bahtiar, dan Ambo Upe
}

\begin{abstract}
Abstrak
Tujuan penelitian ini adalah 1) Untuk mengetahui bentuk kebudayaan Kaseise dalam acara pelaksanaan hari pelepasan kematian (Poalo). 2) Untuk mengetahui nilai-nilai sosial yang terkandung dalam budaya Kaseise pada acara pelaksanaan hari pelepasan kematian (Poalo). 3) Untuk mengetahui faktor yang menyebabkan kebudayaan Kaseise masih tetap eksis di Desa Mataindaha Kecamatan Pasikolaga. Penelitian ini dilakukan di Desa Mataindaha Kecamatan Pasikolaga Kabupaten Muna. Sumber data dalam penelitian ini menggunakan data primer yaitu data melalui kegiatan observasi, dan wawancara guna menjawab permasalahan penelitian dan data sekunder yaitu data berupa catatan-catatan dan dokumentasi tentang keadaan geografis lokasi. Penelitian ini merupakan penelitian deskriptif kualitatif. Teknik pengumpulan data yang digunakan adalah wawancara, observasi dan dokumentasi. Untuk teknik penentuan informan menggunakan teknik Snowball Sampling. Teknik analisis data yang digunakan yaitu analisis model interaktif menggunakan tiga tahapan yaitu reduksi data, penyajian data dan penarikan kesimpulan atau verifikasi. Hasil dalam penelitian ini menunjukkan bahwa kebudayaan Kaseise mempunyai dua bentuk yaitu Kaseise dalam bentuk uang dan Kaseise dalam bentuk bahan pokok. Nilai-nilai yang terkandung dalam budaya Kaseise yaitu nilai religi/agama, nilai kebersamaan, nilai sosialisasi, dan nilai ekonomi. Adapun faktor yang menyebabkan kebudayaan Kaseise masih tetap eksis di Desa Mataindaha Kecamatan Pasikolaga karena dua faktor yaitu faktor tradisi dan faktor kewajiban sosial.

Kata Kunci: Poalo, Kaseise, dan Masyarakat
\end{abstract}

\section{PENDAHULUAN}

Kajian tentang budaya tolong-menolong telah banyak di teliti di berbagai daerah. Pada masyarakat jawa Kebudayaan tolong-menolong atau gotong-royong ini dikenal dengan kebudayaan Sambatan (Sulistyo, 2013). Sambatan merupakan suatu sistem gotong-royong dengan cara menggerakkan tenaga kerja secara masal yang berasal dari warga kampung itu sendiri untuk membantu keluarga yang sedang tertimpa musibah atau sedang mengerjakan sesuatu, seperti membangun rumah. Sambatan ini masih banyak dilakukan oleh masyarakat Jawa terutama yang tinggal di daerah pedesaan yang dilakukan secara turun-temurun sampai sekarang. Sejalan dengan kajian tersebut, konsep budaya tolong-menolong Lampung di Desa Negeri Agung, Kabupaten Waykanan dengan istilah Sakai Sambayan (Oktariana, 2016), dilakukan dengan cara gotong-royong, tolong-menolong, dan saling memberi terhadap sesuatu yang diperlukan oleh individu lain. Sakai Sambayan tidak hanya berupa materil tetapi juga berupa moril termasuk sumbangan pemikiran. Budaya Sakai Sambayan mengandung banyak kebaikan bagi kehidupan masyarakat, sehingga 
prinsip ini mentradisi dan melekat pada kehidupan masyarakat. Selanjutnya, kajian tentang budaya tolong-menolong dilakukan oleh (Sismudjito, 2016) yang menemukan Tradisi Margugu Sebagai Sistem Tolong Menolong Pada Masyarakat di Desa Marubun Lokkung, Kecamatan Dolok Silau Kabupaten Simalungun Sumatra Utara. Margugu ini yang merupakan salah satu tradisi tolong-menolong yang diwariskan oleh para pendahulu desa Marubun Lokkung. Sesuai dengan pemikiran Ibnu Khaldun (2011) mengenai solidaritas sosial bahwa hidup bersama dan saling tolong-menolong merupakan kebutuhan pokok manusia karena apabila itu tidak dilaksanakan jenis manusia ini akan punah dan kolektifisme menjadi prasyarat utama terbentuknya pranata sosial, dimana manusia secara individu tidak akan mampu hidup sendiri.

Pada masyarakat Bugis budaya tolong-menolong tertuang dalam falsafah hidup "Rebba sipotokkong, mali siparappe, sirui menre tessurui nok, malillu sipakainge maingepi mираja". Artinya rebah saling menegakkan, hanyut saling mendamparkan, saling menarik ke atas dan tidak saling menekan kebawah, terlupa saling mengingatka, nanti sadar atau tertolong barulah berhenti. Filosofi tersebut memberi pesan agar orang selalu berpijak dengan teguh dan berdiri kokoh dalam mengarungi kehidupan. Harus tolong-menolong ketika menghadapi rintangan dan saling mengingatkan untuk menuju jalan yang benar. Filosofi hidup masyarakat bugis inilah yang menjadi pegangan hidup di mana pun mereka berada dan dalam aktivitas apapun yang dianggap baik (Upe dan Juhaepa, 2011). Sedangkan pada masyarakat Muna budaya gotong royong/tolong-menolong secara umum dikenal dengan budaya Pokadulu, yaitu dilakukan pada kegiatan pembangunan rumah, bercocok tanam, dan perkawinan (Monayati, 2016). Selain itu, pada masyarakat Muna khususnya di Desa Mataindaha mempunyai kebudayaan tolong menolong lainnya yaitu kebudayaan Kaseise yang diterapkan hanya pada Pelaksanaan hari pelepasan kematian (Poalo) dengan hari-hari yang telah ditentukan yaitu dari hari pertama Poalo sampai pada hari ke tujuh. Kebudayaan Kaseise adalah bentuk tolong-menolong temasuk didalamnya gotong-royong dan juga kerjasama. Bentuk tolong-menolong dalam budaya Kaseise ini adalah pemberian uang kepada keluarga yang meninggal dunia dengan tujuan meringankan beban ekonomi pada keluarga tersebut.

Kaseise memang sangat berkaitan erat dengan sikap toleransi yang tinggi. Hal ini merupakan modal awal bagi individu untuk menjalankan kehidupan sosial. Individu adalah makhluk sosial, dan makhluk sosial tidak dapat hidup sendir. Jadi perlunya interaksi dan kerjasama yang baik dengan individu yang lain untuk memenuhi kebutuhan hidup. Disinilah makna Kaseise tersebut perlu diterapkan. Setelah menjalin hubungan dan kerjasama yang baik, menjunjung tinggi sikap toleransi, meningkatkan rasa simpati dan empati diri, pada masa yang akan datang seseorang tidak akan kesulitan untuk berpartisipasi dalam kegiatan masyarakat.

Budaya Kaseise memang sudah sedikit memudar di wilayah perkotaan, karena pada umumnya masyarakat perkotaan lebih bersifat individual dan juga tidak saling mengenal karena banyak masyarakat pendatang atau bukan penduduk asli Muna. 
Akan tetapi di Desa Mataindaha, Kecamatan Pasikolaga masilah sangat kental. Bapak Salili selaku Kamokulano Liwu (Orang Tua Kampung) di Desa Mataindaha Kecamatan Paikolaga mengatakan bahwa budaya Kaseise di Desa tersebut dari tahun ke tahun selalu meningkat. Masyarakat memiliki antusias yang cukup tinggi dalam hal tolong-menolong. Masyarakat disana memiliki rasa simpati dan empati yang tinggi, mereka tak segan untuk saling membantu. Di Desa Mataindaha Kecamatan Pasikolaga masyarakatnya masih sangat kekeluargaan.

Tolong-menolong menurut saya sangat dibutuhkan oleh setiap individu, karena tidak ada invidu yang dapat bertahan hidup tanpa ada bantuan dari orang lain, inilah yang disebut sebagai makhluk sosial. Bantuan tersebut baik berupa tenaga, pemikiran maupun dalam bentuk uang. Ketika budaya tolong-menolong ini sudah terinternalisasi dalam diri masing-masing individu maka akan terjalinlah kerjasama, dan ketika kerjasama selalu aktif dilakukan dalam masyarakat, maka dari sinilah solidaritas sosial terbentuk.

Dengan demikian ada dua yang menjadi rumusan masalah pada penelitian ini, yaitu sebagai berikut: (1) Bagaimana bentuk kebudayaan Kaseise dalam acara pelaksanaan hari pelepasan kematian (Poalo)? (2) Nilai-nilai sosial apakah yang terkandung dalam budaya Kaseise pada acara pelaksanaan hari pelepasan kematian (Poalo)? (3) Faktor apakah yang menyebabkan kebudayaan Kaseise masih tetap eksis di Desa Mataindaha Kecamatan Pasikolaga?

\section{METODE PENELITIAN}

Penelitian ini dilaksanakan di Desa Mataindaha Kecamatan Pasikolaga Kabupaten Muna, dengan pertimbangan bahwa di Desa tersebut merupakan Desa yang masih mempertahankan dan mempraktekan budaya Kaseise sampai saat ini di dalam proses pelaksaan hari pelepasan kematian (Poalo).

Untuk mendapat informan sehubung dengan penelitian ini, maka informan dalam penelitian ini dilakukan dengan menggunakan teknik purposive sampling (disengaja). Dengan pertimbangan bahwa informan tersebut dapat mengetahui dan memberikan jawaban atau informasi yang akurat atas permasalahan penelitian ini yakni mengenai pelaksanaan budaya Kaseise pada masyarakat di Desa Mataindaha.

Adapun yang menjadi informan dalam penelitian ini meliputi informan kunci dan informan biasa. Informan kunci yakni tokoh adat 1 orang, tokoh agama 3 orang, tokoh masyarakat 2 orang dan Kepala Desa Mataindaha yang dipercaya oleh masyarakat yang mempunyai pengetahuan lebih mengenai budaya Kaseise. Peneliti menunjukan informan kunci di atas, karena menguasai permasalahan dalam penelitian ini. Sedangkan informan biasa yakni masyarakat secara umum 8 orang, sehingga jumlah informan dalam penelitian ini 14 orang.

Sumber data yang digunakan dalam penelitian ini adalah: Data primer yakni data yang akan diperoleh dari hasil pengamatan dan wawancara langsung dengan nara sumber yang banyak mengetahui pelaksanaan budaya Kaseise. Data sekunder yakni data yang berupa catatan dari dokumen-dokumen yang terdapat di kantor 
Desa Mataindaha, mengenai jumlah penduduk dan data yang relevan dengan penelitian ini. Adapun jenis data yang digunakan dalam penelitian ini bersifat deskriptif kualitatif yakni data yang menjelaskan fenomena yang empiris yang sesuai dengan fakta di lapangan.

Teknik pengumpulan data dalam penelitian ini adalah pengamatan (observasi), yaitu pengumpulan data dengan cara melakukan pengamatan terhadap objek penelitian adalah dengan melihat berbagai macam aktifitas masyarakat Desa Mataindaha, hal ini dilakukan saat tahap studi eksplorasi guna mencari informasi awal dalam penelitian ini. Wawancara (interview), yaitu teknik yang digunakan untuk memperoleh informasi langsung dan lebih mendalam sehingga dapat memahami kebudayaan Kaseise pada masyarakat Desa Mataindaha, dan dokumentasi yaitu mengambil data-data dari dokumen-dokumen serta literatur yang ada kaitannya dengan penelitian ini.

Dalam penelitian ini, peneliti menggunakan analisis data model Miles dan Huberman, mengemukakan bahwa aktivitas dalam analisis data kualitatif dilakukan secara interaktif dan berlangsung secara terus menerus sampai tuntas, sehingga datanya sudah jenuh, aktifitas dalam analisis data Miles dan Huberman (Upe, 2016) yaitu sebagai berikut. Reduksi Data (data reduction). Reduksi data diartikan sebagai proses pemilihan, pemusatan perhatian pada penyederhanaan, pengabstrakan, dan transformasi data "kasar" yang muncul dari catatan tertulis di lapangan dan memfokuskan pada hal-hal penting dari sejumlah data lapangan yang telah diperoleh dan mencari polanya. Reduksi data berlangsung terus-menerus selama penelitian berlangsung. Penyajian Data (data display), setelah hasil dari seperangkat reduksi, maka data tersebut diorganisasikan kedalam bentuk tertentu sesuai kemauan data, data dibiarkan sebebas-bebasnya, sedalam-dalamnya, dan yang sesungguhnya. Untuk melihat gambaran seutuhnya atau bagian-bagian tertentu dari penelitian, maka data tersebut disajikan (data display) dalam berbagai macam bentuk. Penyajian data dilakukan dalam bentuk uraian singkat, hubungan antarkategori, bagan, dan teks yang bersifat naratif baik yang bersumber dari petikan wawancara, hasil observasi, maupun dari dokumen, dan penarikan Kesimpulan (conclusion drawing/verivication) proses pengumpulan data bukan merupakan langkah terakhir dan akan berhenti disitu, melainkan kesimpulan tersebut masih bersifat tentatif, kabur, diragukan, dan akan berubah jika tidak ditemukan bukti-bukti yang kaut. Karena itu kesimpulan selalu dilakukan pendalaman data secara interaktif hingga ditemukan kesimpulan yang benar-benar kredibel, tingkat keteralihan yang tinggi, konsisten, dan ketika dilakukan konfirmasi menghasilkan informasi yang sama. 


\section{PEMBAHASAN}

\section{Bentuk Kebudayaan Kaseise dalam Pelakasanaan Hari Pelepasan Kematian (Poalo)}

\section{Kaseise dalam Bentuk Uang}

Bahwa masyarakat Desa Mataindaha di Kecamatan Pasikolaga mempunyai kebudayaan tentang tolong menolong (Kaseise) yakni dari kalangan para laki-laki mempunyai Kaseise tersendiri yaitu melakukan pembayaran uang sebesar Rp 5.000.

\section{Kaseise dalam Bentuk Bahan Pokok}

Bentuk tolong menolong ini terkhusus dilakukan oleh para wanita (ibu-ibu), mereka memberikan bahan pokok seperti beras, pisang, telur, ayam, dan lain sebagainya.

\section{Nilai-Nilai Sosial Budaya Yang Terkandung Dalam Budaya Kaseise}

\section{Nilai Religi/Agama}

Nilai religius memiliki kedudukan yang sentral dalam kebudayaan Kaseise sehingga mempengaruhi eksistensinya dalam kehidupan masyarakat karna di samping mendapatkan balasan dari manusia dan juga tatkala pentingnya mendapatkan pahala dari Allah SWT. Nilai agama dalam Kaseise tidak terlepas dari konsep nilai agama suatu masyarakat. Dalam kaitan ini, agama merupakan sistem yang terdiri dari konsep-konsep yang dipercaya dan menjadi keyakinan mutlak suatu umat, serta hubungan manusia dengan alam sekitar, manusia, dan alam gaib. Kehadiran agama Islam di Muna membawa pengaruh yang sangat besar dengan kehidupan masyarakat. Hal ini tercermin dari pola pikir, aturan-aturan, gagasangagasan, dan keyakinan yang berkembang dalam masyarakat.

\section{Nilai Kebersamaan}

Tolong menolong mencerminkan kebersamaan yang tumbuh dalam lingkungan masyarakat. Dengan tolong menolong masyarakat mau bekerja sama untuk membantu orang lain atau untuk membangun fasilitas yang bisa di manfaatkan bersama. Dengan anggapan bahwa manusia merupakan makhluk sosial yang tidak dapat hidup sendiri melainkan adanya keterlibatan manusia lain dalam berbagai aspek kehidupan. Tolong menolong yang ada dalam suatu masyarakat membentuk mentalitas bangsa menjadi lebih berkarakter dan melahirkan banyak nilai-nilai luhur yang bermanfaat bagi kehidupan. Begitu pula dengan budaya Kaseise yang ada pada masyarakat Desa Mataindaha, mencerminkan asas kebersamaan sehingga membentuk rasa persaudaraan yang jauh lebih dekat. Kebersamaan masyarakat Desa Mataindaha yang terjalin dalam tolong menolong sekaligus melahirkan persatuan antar anggota masyarakat. Dengan persatuan yang ada, masyarakat menjadi lebih kuat dan mampu menghadapi berbagai permasalahan yang muncul. Tolong menolong dapat memupuk persatuan dan kesatuan antar manusia.

\section{Nilai sosialisasi}

Proses sosialisasi telah berlangsung cukup lama yang dilakukan oleh para orang tua terdahulu, dan generasi yang ada sekarang memahami bahwa Kaseise itu sangat penting dalam kehidupan masyarakat transformasi melalui tindakan maupun 
pengetahuan oleh para orang tua terdahulu maupun masyarakat terhadap regenerasi sehingga budaya Kaseise masi tetap eksis dan diterapkan oleh masyarakat sampai sekarang.

\section{Nilai Ekonomi}

Pada dasarnya kebudayaan diciptakan oleh manusia karna menurut mereka dengan adanya kebudayaan tersebut dapat memberikan asas manfaat bagi masyarakat secara umum. Kebudayaan Kaseise inilah yang mereka bentuk dan mempunyai banyak manfaat dan untuk kehidupan masyarakat terkhusus dalam kondisi ekonomi atau kondisi keuangan. Dengan adanya kebudayaan tolong meolong (Kaseise) dalam pelaksanaan hari pelepasan (Poalo) secara ekonomi dapat terbantu bagi keluarga yang meninggal dunia, dalam hal ini adalah acara pelaksanaan hari pertama Poalo, hari ketiga Poalo (Itolu), Patai, dan hari ketujuh Poalo (Ifitu), adapun manfaat ekonominya sebagai berikut:

1. Dengan adanya kebudayaan tolong menolong (Kaseise) yang terdapat dalam Poalo ini dapat membantu meringankan beban keluarga yang meninggal dunia dalam hal melancarkan pelaksanaan hari pelepasan kematian (Poalo).

2. Ketika pelaksanaan hari pelepasan kematian (Poalo) diadakan seacar besarbesaran maka keluarga-keluaga akan berkumpul dan bisa menjalin silaturahim kembali, karna dalam acara tersebut menyebatrkan undangan untuk keluarga.

3. Selain silaturahim bersama keluarga, dengan adanya acara tersebut dapat memberikan manfaat silaturahim pada warga masyarakat dalam desa dan warga masyarakat desa-desa tetangga.

\section{Faktor Yang Menyebabkan Eksistensi Kaseise di Desa Mataindaha}

\section{Faktor Tradisi}

Pulau Muna memiliki berbagai macam budaya yang sudah berakar dan di yakini telah ada pada masyarakat seiring dengan keberadaan mereka di pulau Muna, namun dengan perkembangan dan akibat modernisasi hasil-hasil kebudayaan tersebut mulai mengalami perubahan, bahkan cenderung di tinggalkan. Padahal budaya tersebut memiliki nilai-nilai yang sangat bermanfaat bagi kelangsungan hidup masyarakatnya. Salah satu budaya tradisional yang masih sering di laksanakan adalah budaya Kaseise yang lahir sebagai akibat pembaruan antara budaya lokal dan budaya Islam. Budaya Kaseise (Tolong menolong) merupakan tradisi pemberian bantuan terhadap masyarakat lain dengan yang berupa materil dengan tujuan meringankan beban keluarga yang meninggal dunia, yang kerap dilaksanakan dari dulu sampai sekarang di wilayah bagian timur Muna yakni di Kecamatan Pasikolaga dan Kecamatan Pasir Putih.

Pulau Muna memiliki berbagai macam budaya yang sudah berakar dan di yakini telah ada pada masyarakat seiring dengan keberadaan mereka di pulau Muna, namun dengan perkembangan dan akibat modernisasi hasil-hasil kebudayaan tersebut mulai mengalami perubahan, bahkan cenderung di tinggalkan. Padahal budaya tersebut memiliki nilai-nilai yang sangat bermanfaat bagi kelangsungan hidup masyarakatnya. Salah satu budaya tradisional yang masih sering di laksanakan adalah 
budaya Kaseise yang lahir sebagai akibat pembaruan antara budaya lokal dan budaya Islam. Budaya Kaseise (Tolong menolong) merupakan tradisi pemberian bantuan terhadap masyarakat lain dengan yang berupa materil dengan tujuan meringankan beban keluarga yang meninggal dunia, yang kerap dilaksanakan dari dulu sampai sekarang di wilayah bagian timur Muna yakni di Kecamatan Pasikolaga dan Kecamatan Pasir Putih.

\section{PENUTUP}

\section{Kesimpulan}

1. Kaseise pada masyarakat Muna khususnya Desa Mataindaha Kecamatan Pasikolaga terbagi dua bentuk:

a. Kaseise dalam bentuk uang, yaitu Kaseise ini dilakukan oleh kalangan laki-laki dengan memberikan uang tunai sebesar Rp 5.000 kepada keluarga yang meninggal dunia.

b. Kaseise dalam bentuk bahan pokok, Kaseise ini dilakukan oleh para kaum wanita dengan memberikan bahan pokok seperti minyak goreng, minyak tanah, beras, telur, dan lain sebagainya.

2. Nilai-nilai sosial yang terkandung dalam budaya Kaseise (Tolong menolong)

a. Nilai religi yang ada dalam budaya Kaseise (tolong menolong) mempunyai nilai ibadah yang tentunya akan bermanfaat di dunia dan di akhirat. Karna kebaikan yang dilakukan akan kembali pada diri sendiri.

b. Nilai kebersamaan yang ada dalam budaya Kaseise (tolong menolong) sangat bermanfaat bagi kehidupan sosial pada suatu daerah maupun wilayah tertentu.

c. Nilai sosialisasi menjadikan masyarakat paham tentang pentingnya eksistensi kebudayaan Kaseise, transformasi melalui tindakan maupun pengetahuan oleh para orang tua terdahulu maupun masyarakat terhadap regenerasi sehingga budaya Kaseise akan tetap eksis dan diterapkan oleh masyarakat sampai sekarang.

d. Nilai ekonomi sangat bermanfaat dalam meringankan beban ekonomi dalam acara pelaksanaan kematian (Poalo)

3. Faktor yang menyebabkan Kaseise masih tetap eksis di Desa Mataindaha Kecamatan Pasikolaga.

a. Faktor tradisi yang menyebabkan Kaseise masi tetap eksis sampai sekarang karena masyarakat Desa identik dengan keloyalan terhadap kebudayaan.

b. Faktor kewajiban sosial, dimana manusia tidak dapat bertahan hidup tanpa bantuan orang lain, akhirnya dia akan membantu saudara-saudaranya karna prinsip timbal balik (reciprocity). Yang mendorong individu untuk berprinsip resiprositas karena adanya sanksi sosial di wilayah tersebut. 


\section{Saran}

Dari kesimpulan hasil penelitian tersebut penulis mengajukan beberapa saran sebagai berikut:

1. Diharapkan kepada seluruh masyarakat Kabupaten Muna untuk terus mempertahankan dan menerapkan budaya Kaseise dalam aktivitas sosial maupun kearifan lokal lainnya sebagai kekayaan budaya dan identitas masyarakat Muna.

2. Bagi mahasiswa yang akan melakukan penelitian selanjutnya hendaknya lebih mengembangkan pembahasan yang diteliti dan mencari referensi lebih lengkap untuk memudahkan dalam mendapatkan data yang lebih baik dan akurat serta dapat menjadi rujukan dalam penelitian yang serupa dengan penelitian ini.

3. Bagi pemerintah daerah seharusnya memperhatikan kebudayaan-kebudayaan lokal yang ada di pedesaan termasuk kebudayaan Kaseise yang ada di kabupaten Muna, karna kebudayaan ini dapat dijadikan sebagai sebuah kearifan lokal.

\section{DAFTAR PUSTAKA}

Monayanti, M. 2016. Pokadulu Sebagai Komunikasi Sosial Masyarakat Muna. Skripsi. Universitas Halu Oleo.

Oktariana, Dila. 2016. Pengaruh Kebudayaan Sakai Sambayan Terhadap Solidaritas Sosial. Skripsi: Universitas Lampung.

Sismudjito. 2016. Tradisi Margugu Sebagai Sistem Tolong Menolong Pada Masyarakat Desa Marubu Lokkung, Kecamatan Dolok Silau Kabupaten Simalungung.

Sulistyo, Ela. 2013. Tradisi Sambatan Membangun Rumah Dalam Kehidupan Masyarakat Jawa. Makalah. Studi Pendidikan Bahasa Dan Sastra Jawa, Fakultas Bahasa Dan Seni. Universitas Negri Semarang.

Upe, Ambo dan Juhaepa. 2011. Eksistensi Nilai Tolong-Menolong Pada Masyarakat Bugis (Kajian atas Assitulung-Tulungeng pada Prosesi Pernikahan. Jurnal Sumber Daya Insani. Universitas Muhamadiyah Kendari. Edisi 2011 No. 20.

Upe, Ambo. 2016. Metode Penelitian Sosial: Filosofi dan Desain Praktis. Kendari: Literacy Institute. 